\title{
Technologies for Cancer Research
}

\author{
Tania Limongi* \\ DISAT - Department of Applied Science and Technology, Politecnico di Torino, Italy
}

*Corresponding author: Tania Limongi, DISAT - Department of Applied Science and Technology, Politecnico di Torino, Italy

\begin{tabular}{|c|c|}
\hline ARTICLE INFO & ABSTRACT \\
\hline Received: 慧 January 22, 2020 & Citation: Tania Limongi. Technologies for Cancer Research. Biomed J Sci \& Tech Res \\
\hline Published: & 25(1)-2020. BJSTR. MS.ID.004141. \\
\hline
\end{tabular}

\section{Opinion}

From an ever wider collection of scientific publications and from the continuous updates provided by the mass media, it is clear how the interconnection between technology and oncology is now close and profitable. By now, the fight against this scourge that strikes with almost no discrimination of age, sex or social position, is conducted with huge expenditure of economic resources and personnel by doctors, engineers, chemists, computer scientists and statisticians. Progresses in many different technological contests are bit by bit contributing to make cancer a handier disease by adding new alternative materials and methods able to efficient treatment to be included in the arsenal available to oncologists.
In an increasingly personalized medicine scenario, the use of new smart materials and technologies opens up new possibilities for the application of micro/nanoparticles [1,2], lab on chips [3] and a whole series of more or less engineered biological components for drug delivery, diagnosis or treatment in cancer management [4-6]. In order to assess data about the topic 'cancer technology', in the January of 2020, I conducted a literature search, using the Thomson Reuters Web of Science research portal. Results showed 44,585 records that were analysed and summarized sorting data by read count and setting the minimum record count to 100, considering both the 'Web of Science Categories' (Table 1) and the 'Counties/ Regions' (Figure 1) point of view.

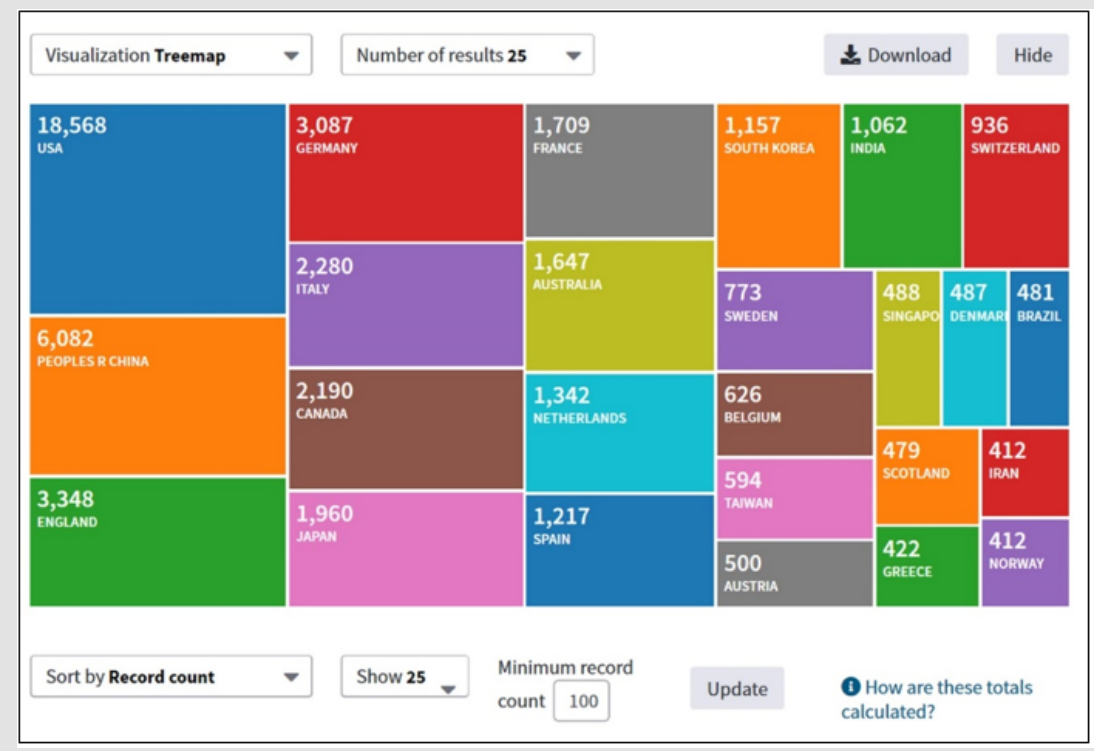

Figure 1: The 'Counties/Regions' (Figure1) point of view. 
The results highlighted how much technology, in terms of radiology, nanotechnology, design of new surgery equipment's or human tissue substitute, contributes to assisting other subjects such as biochemistry, cellular and molecular biology, pharmacology and pathology in the fight against cancer (Table 1). wild and transversal is the literature that can relate to this type of research and it clearly shows how the scientific production is centered on nanotechological, pharmacological and chemical aspects. In my opinion it is very interesting and encouraging to note that the contribution in terms of number of scientific publications for the period under consideration is very high even in the case of small geographical realities or in the case of regions that do not yet have a large number of funds. This fact must give us hope because, in any case, it indicates that we are going in the right direction, with a strong sharing of intent. Many new technologies still have to attest their value and safety in oncological clinical trials, however, a future where cancer handling is successfully personalized it is more and more likely.

Table 1: Results showed 44,585 records that were analysed and summarized sorting data by read count and setting the minimum record count to 100, considering both the 'Web of Science Categories'.

\begin{tabular}{|c|c|c|}
\hline Web of Science Categories & Records & $\%$ of 44585 \\
\hline ONCOLOGY & 9765 & 21.902 \\
\hline BIOCHEMISTRY MOLECULAR BIOLOGY & 3317 & 7.440 \\
\hline RADIOLOGY NUCLEAR MEDICINE MEDICAL IMAGING & 3130 & 7.020 \\
\hline PHARMACOLOGY PHARMACY & 2922 & 6.554 \\
\hline BIOCHEMICAL RESEARCH METHODS & 2735 & 6.134 \\
\hline BIOTECHNOLOGY APPLIED MICROBIOLOGY & 2589 & 5.807 \\
\hline MEDICINE RESEARCH EXPERIMENTAL & 2470 & 5.540 \\
\hline CELL BIOLOGY & 1872 & 4.199 \\
\hline GENETICS HEREDITY & 1859 & 4.170 \\
\hline SURGERY & 1682 & 3.773 \\
\hline MULTIDISCIPLINARY SCIENCES & 1674 & 3.755 \\
\hline CHEMISTRY MULTIDISCIPLINARY & 1556 & 3.490 \\
\hline NANOSCIENCE NANOTECHNOLOGY & 1474 & 3.306 \\
\hline ENGINEERING BIOMEDICAL & 1424 & 3.194 \\
\hline PATHOLOGY & 1421 & 3.187 \\
\hline CHEMISTRY ANALYTICAL & 1417 & 3.178 \\
\hline HEALTH CARE SCIENCES SERVICES & 1403 & 3.147 \\
\hline GASTROENTEROLOGY HEPATOLOGY & 1343 & 3.012 \\
\hline MEDICINE GENERAL INTERNAL & 1183 & 2.653 \\
\hline UROLOGY NEPHROLOGY & 1119 & 2.510 \\
\hline PUBLIC ENVIRONMENTAL OCCUPATIONAL HEALTH & 1094 & 2.454 \\
\hline ENGINEERING ELECTRICAL ELECTRONIC & 1036 & 2.324 \\
\hline OPTICS & 999 & 2.241 \\
\hline OBSTETRICS GYNECOLOGY & 975 & 2.187 \\
\hline MATHEMATICAL COMPUTATIONAL BIOLOGY & 874 & 1.960 \\
\hline \multicolumn{2}{|c|}{ (204 Web of Science Categories value(s) outside display options.) } & \\
\hline
\end{tabular}

\section{References}

1. Dumontel B, Francesca Susa, Tania Limongi, Marta Canta, Luisa Racca, et al. (2019) ZnO nanocrystals shuttled by extracellular vesicles as effective Trojan nano-horses against cancer cells. Nanomedicine (Lond) 14(21): 2815-2833.

2. Limongi T, Susa F, Cauda V (2019) Nanoparticles for hematologic diseases detection and treatment.

3. Malara N, Coluccio ML, Limongi T, Asande M, Trunzo V, et al. (2014) Folic acid functionalized surface highlights 5-methylcytosine-genomic content within circulating tumor cells. Small 10(21): 4324-4331.
4. Riley RS, June CH, Langer R, Mitchell MJ (2019) Delivery technologies for cancer immunotherapy. Nat Rev Drug Discov 18(3): 175-196.

5. Marino A, Alice Camponovo, Andrea Degl'Innocenti, Martina Bartolucci, Christos Tapeinos, et al. (2019) Multifunctional temozolomide-loaded lipid superparamagnetic nanovectors: dual targeting and disintegration of glioblastoma spheroids by synergic chemotherapy and hyperthermia treatment. Nanoscale 11(44): 21227-21248.

6. Stevic I, Buescher G, Ricklefs FL (2020) Monitoring Therapy Efficiency in Cancer through Extracellular Vesicles. Cells 9(1): 130. 
ISSN: 2574-1241

DOI: 10.26717/BJSTR.2020.25.004141

Tania Limongi. Biomed J Sci \& Tech Res

(C) This work is licensed under Creative

Submission Link: https://biomedres.us/submit-manuscript.php

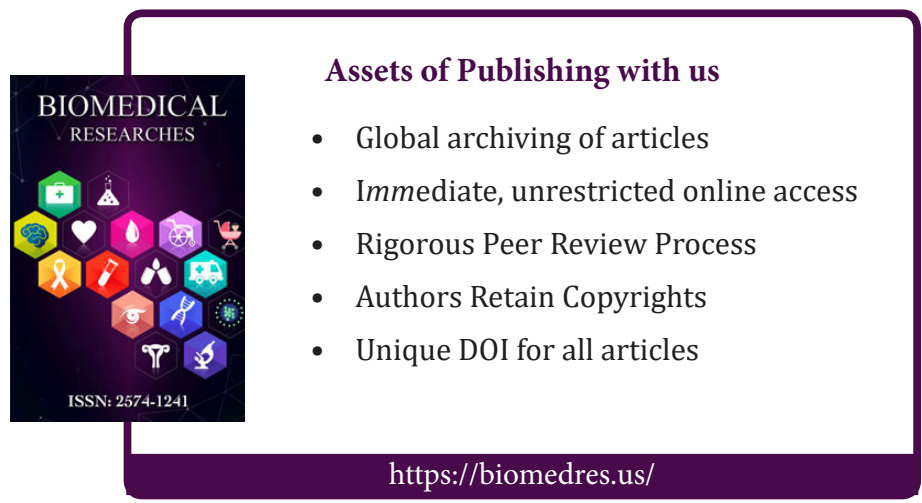

